\title{
DIFFERENCES IN SPATIAL MATHEMATICAL ABILITY OF STUDENTS GIVEN A MODEL LEARNING REALISTIC MATHEMATIS EDUCATION WITH STAD TYPE OF COOPERATIVE LEARNING
}

\author{
Ara Yustiana ${ }^{1}$, Edi Syahputra ${ }^{2}$, Anita Yus ${ }^{3}$ \\ ${ }^{1,2,3}$ Pendidikan Matematika, Program Pascasarjana Universitas Negeri Medan, Jl. Willem Iskandar Pasar V Kenangan \\ Baru, PercutSei Tuan, Deli Serdang, Indonesia, 20221 \\ Arayustiana05@gmail.com
}

\begin{abstract}
The focus of this research is to analyze the students' spatial abilities and mathematical dispositions in 2 cooperative learning models. This study aims to determine (1) Is there any significant difference between students' spatial abilities taught by using Realistic Mathematic Education (RME) learning and students' spatial abilities taught by using STAD type of cooperative learning? (2) is there any interaction between learning and students' initial mathematics abilities against students' spatial abilities ? This research is a quasi-experimental research. The population of this study were students of class X MAN 2, 2019/2020 Deli Serdang. The research sample was taken randomly in order to obtain two sample classes. The experimental class I received the Realistic Mathematic Education (RME) learning model and the experimental class II received the STAD type of cooperative learning. The instrument are consisted of a spatial ability test and a learning disposition questionnaire. Data analysis was performed using two-way analysis of variance (ANOVA). The results showed that (1) there was a significant difference between students' spatial abilities taught by using Realistic Mathematic Education (RME) learning and students' spatial abilities taught by using STAD type of cooperative learning (2) there was an interaction between learning and students' initial mathematical abilities towards their spatial abilities.
\end{abstract}

Keywords:Realistic Mathematic Education (RME), students' initial mathematics abilities, Student Teams Achievement Division (STAD), Spatial, ANAVA

\begin{abstract}
Abstrak
fokus penelitian ini adalah untuk menganalisis kemampuan spasial dan disposisi matematis siswa pada 2 model pembelajaran kooperatif. Penelitian ini bertujuan untuk mengetahui (1) apakah terdapat perbedaan yang signifikan antara kemampuan spasial siswa yang diajar melalui pembelajaran Realistic Mathematic Education $(R M E)$ dan kemampuan spasial siswa yang diajar melalui pembelajaran kooperatif tipe STAD? (2) apakah terdapat interaksi antara pembelajaran dan kemampuan awal matematika siswa terhadap kemampuan spasial siswa? Penelitian ini merupakan penelitian eksperimen semu. Populasi penelitian ini adalah siswa kelas $\mathrm{X}$ MAN 2 Deli Serdang. Sampel penelitian diambil secara acak sehingga diperoleh dua kelas sampel. Kelas eksperimen I mendapat model pembelajaran Realistic Mathematic Education (RME) dan kelas eksperimen II mendapat pembelajaran kooperatif tipe STAD. Instrumen yang digunakan terdiri dari tes kemampuan spasial dan angket disposisi belajar. Analisis data dilakukan dengan analisis varians dua jalur (ANAVA). Hasil penelitian menunjukkan bahwa (1) terdapat perbedaan yang signifikan antara kemampuan spasial siswa yang diajar melalui pembelajaran Realistic Mathematic Education (RME) dan kemampuan spasial siswa yang diajar melalui pembelajaran kooperatif tipe STAD (2) terdapat interaksi antara pembelajaran dan kemampuan awal matematika siswa terhadap kemampuan spasial siswa.
\end{abstract}

Kata Kunci: Realistic Mathematic Education (RME), KemampuanAwalMatematik (KAM), Student Teams Achievement Division (STAD), Spasial, ANAVA

\section{INTRODUCTION}

Mathematics is an applied science that can be applied in various forms. Almost all human activities are related to mathematics (Fitri, Syahputra, \& Syahputra, 2019; Kulsum, Hidayat, Wijaya, \& Kumala, 2019; Wijaya, Purnama, \& Tanuwijaya, 2020). In addition, mathematics is one of the most preferred fields of study during the teaching and learning process in schools (Desania, Sinaga, Lubis, 
\& Syahputra, 2020; Wijaya, Sukma, Purnama, \& Tanuwijaya, 2020). This can be seen from the lesson hours that students must take in school. Not only at school, even the majority of parents at home provide their children with additional mathematics learning by enrolling their children to take math courses. In addition, mathematics is one of the basic sciences that has a very important influence in life (Dini, Wijaya, \& Sugandi, 2018), because it can prepare and develop students' abilities to think logically, kindly, and appropriately to solve problems that occur in everyday life (S. N. Dewi, Wijaya, Budianti, \& Rohaeti, 2018; Hutajulu, Wijaya, \& Hidayat, 2019; Napitupulu, Syahputra, \& Sinaga, 2020). Formal education in Indonesia has not provided sufficient stimulation for the development of children's intelligence, because it only develops certain abilities and does not stimulate the function and role of the right brain.

To improve learning outcomes as planned, an increase in the learning process is needed (Bernard, Sumarna, Rolina, \& Akbar, 2019; Syahputra \& Utami, 2019). A quality learning process is a necessity. Various efforts have been made by the government to improve the quality of human resources in Indonesia. One of the steps is to develop learning tools (Syahputra\&Utami, 2019). The material presented must be combined with a learning model that is in accordance with the needs of students so that learning is more comfortable. In addition to depending on the learning approach or model, student achievement in the learning process is also influenced by students' initial mathematical abilities, or what is often referred to as KAM. Initial ability describes the readiness of students to receive lessons that will be delivered by the teacher (Napitupulu, Syahputra, \&Sinaga, 2020). The formation of initial abilities is influenced by the quality of learning experienced by students if previous learning is not effective, then the learning outcomes cannot achieve the learning objectives that have been set (Fitri, Syahputra, \& Syahputra, 2019).

The current condition is that students' mathematical thinking skills in Indonesia have not developed optimally and are still low (Aminah, Wijaya, \& Yuspriyati, 2018). Facts that can be used as indicators of the low quality of mathematics learning in Indonesia, such as the results of the Trends in International Mathematics and Science Study (TIMSS) and the Program for International Student Assessment (PISA) (Purnama, Wijaya, Dewi, \& Zulfah, 2020). From the results shown by TIMMS and PISA Indonesia only mastered lessons up to level 3 or intermediate level, while many other countries had levels 4, 5, even 6. Research by TIMSS 2007, TIMSS 2011, and PISA 2009 explained that Indonesian students ability to answer mathematics to a low international standard.

In mathematics geometry is the key to understanding nature with all its forms in the world. According to Kartono (Khotimah, 2013) based on a psychological point of view, geometry is an abstraction presentation of visual and spatial experiences, for example fields, patterns, measurements and mapping. Geometry not only develops students' cognitive abilities but also helps in forming memory, namely concrete objects to be abstract (Wijaya, Tang, \& Purnama, 2020). Based on this opinion, geometry is an important material in learning mathematics. In geometry, spatial ability is not only an ability that students only have to master in order to better understand the concept of spatial 
shapes, but spatial ability itself indirectly affects overall mathematics learning outcomes (Wijaya, Ying, \& Suan, 2020). If viewed from the context of everyday life, spatial abilities also need to be improved because spatial abilities do not only play an important role in success in mathematics and other subjects. However, in reality the students' spatial abilities are still low and problematic. Some of the findings that occurred at MAN 2 Deli Serdangschool were based on the results of diagnostic tests that students still had difficulty understanding and solving questions designed to develop students' spatial abilities.

In this problem there are still many teachers who apply conventional learning (Wijaya, Dewi, Fauziah, \& Afrilianto, 2018; Zhang, Zhou, \& Wijaya, 2020). Such learning (teacher centered) is already considered traditional and is no longer suitable for use (D. P. Dewi, Mediyani, Hidayat, Rohaeti, \& Wijaya, 2019). This is because students cannot be creative and express their ideas, students are only given various information and exercises regarding the material. Students should build their own thinking patterns related to mathematical ideas and concepts, so that if there is a problem or condition in various forms, students can solve the problem. In this case the researcher seeks to improve spatial abilities by creating innovative mathematics learning, involving cognitive, affective and psychomotor aspects. In order to further optimize the students' spatial abilities, the teacher can design a learning process that involves students actively. The teacher involves active student activities during the teaching and learning process and creates teaching materials that have divergent questions. Alternative solutions that can overcome problems in mathematics education are to increase both the quantity and quality of learning through Realistic Mathematic Education (RME) and Cooperative Learning. Learning using the Realistic Mathematic Education approach can make students active and motivated to learn. Meanwhile, cooperative learning can help students improve positive attitudes in mathematics. Individual students build confidence in their ability to solve mathematical problems (Fitriani, Suryadi, \& Darhim, 2018; Tamur, Juandi, \& Adem, 2020).

Spatial abilities are mental abilities that are concerned with understanding, manipulating, rotating, and interpreting visual relationships. The spatial abilities discussed in this study are the students' ability to imagine the shape or position of a geometric object viewed from a certain point of view, state the position between the elements of a space, construct and represent geometric models drawn on a flat plane, and predict and determine the actual size of the visual stimulus of an object .

Learning with Realistic Mathematic Education begins with activities that use concrete objects or contexts that are close to the student's world so that it makes it easier for students to relate to the concept of the lesson. Learning with Realistic Mathematic Education uses a philosophical foundation of constructivism. The view of constructivism is knowledge constructed by humans little by little whose results are extended through a limited context. Learning based on constructivism builds students 'own understanding of new experiences based on students' prior knowledge (Jauhari, Kusmayadi\&Mardiyana, 2014: 16). 
STAD (Student Teams Achievement Division) is one of the simplest cooperative learning methods and is the method most often used. Slavin (2011) states that at STAD students are placed in a learning team of 4-5 people which is a mixture according to level of achievement, gender, and ethnicity. The function of this learning model is to ensure that all members in the team have really studied well and mastered the learning material. Research questions:

1. Is there a significant difference between students 'spatial abilities taught through Realistic Mathematic Education (RME) learning and students' spatial abilities taught through STAD type cooperative learning?

2. Is there any interaction between learning and students 'initial mathematics abilities against students' spatial abilities?

\section{METHOD}

This research uses quantitative research methods with the pretest-posttest method to see the difference between the experimental class and the controlled class. research was conducted at MAN 2 Deli Serdang where the population in this study were all students of MAN 2 Deli Serdang. This study used a randomly selected sample and selected class XI IPA-1 as experimental class I and class XI IPA-3 as experimental class II. The experimental design used in this study was a posttest only control design.

Table 1.

Research design

\begin{tabular}{|l|l|l|}
\hline \multicolumn{1}{|c|}{ Class } & \multicolumn{1}{c|}{ Treatment } & Posttest \\
\hline Eksperimen-1 & $\mathrm{X}_{1}$ & $\mathrm{O}$ \\
\hline Eksperimen-2 & $\mathrm{X}_{2}$ & $\mathrm{O}$ \\
\hline
\end{tabular}

additional :

$\mathrm{X}_{1} \quad$ : teaching and learning activity with $R M E$

$\mathrm{X}_{2} \quad$ : cooperative teachingtype STAD

O : Post test

\section{RESEARCH RESULTS}

The students' mathematical spatial abilities were obtained from the post-test results in the experimental class I and the experimental class II. Processing and analysis of the spatial ability test data aims to determine the spatial abilities of students taught through Realistic Mathematic Education (RME) learning in experimental class I and taught through cooperative learning type STAD in experimental class II. 
Differences In Spatial Mathematical Ability Of Students Given A Model Learning Realistic Mathematis Education With Stad Type Of Cooperative Learning, Ara Yustiana, Edi Syahputra, Anita Yus

\section{Table 2.}

Student Mathematical Spatial Ability Data

\begin{tabular}{|l|l|l|}
\hline \multirow{2}{*}{ Statistics } & \multicolumn{2}{|l|}{ Teaching and learning } \\
\cline { 2 - 3 } & Experiment I & Experiment II \\
\hline N & 36 & 36 \\
\hline Rata-Rata & 80,45 & 71,32 \\
\hline Stdev & 9,69 & 11,17 \\
\hline
\end{tabular}

In Table 2 above, it shows that the average mathematical spatial ability of students who received Realistic Mathematic Education (RME) learning was 80.45, while the average value of students' mathematical spatial abilities in cooperative learning type STAD was 71.32. So the average mathematical spatial ability of students in experimental class I was better than the average mathematical ability of students in experimental class II.

\section{ANOVA Prerequisite Test for Student's Spatial Ability}

The normality test is intended to see whether the data of students' mathematical spatial abilities in both classes is normally distributed or not. This normality test was carried out using the Kolmogorov-Smirnov statistical test on both data classes, with the following hypothesis testing:

$H_{0}$ : The sample comes from a population with a normal distribution.

Ha: The sample comes from a population that is not normally distributed.

The $\mathrm{H}_{0}$ test criterion is accepted if the probability (sig) obtained is greater than 0.05 and is rejected in other cases. To test this hypothesis, the Kolmogorov-Smirnov test was used. The output of the calculation of the data normality test of students' mathematical spatial ability in the experimental class I and experimental class II can be seen in Table 3 below:

\section{Table 3.}

Results of Students' Mathematical Spatial Ability Normality Test

\begin{tabular}{|l|l|l|l|l|}
\hline \multirow{2}{*}{ Special score } & \multirow{4}{*}{ Model } & \multicolumn{4}{|l|}{ Kolmogorov-Smirnov $^{\mathrm{a}}$} \\
\cline { 3 - 5 } & 1 & Statistic & df & Sig. \\
\cline { 2 - 5 } & 2 & .088 & 36 & $.200^{*}$ \\
\hline
\end{tabular}

Based on Table 1.3, it can be seen that the Kolmogorov-Smirnov probability (sig) value of students' mathematical spatial ability in the experimental class I is 0.088 and in the experimental class II is 0.123 . This shows that the probability value (sig) is greater than 0.05 . This means that $\mathrm{H} 0$ is accepted or in other words, the students' mathematical spatial ability data comes from a normally distributed population.

The homogeneity test was carried out using the Homogeneity of Variances (Levene Statistic) test which was intended to test the homogeneity of the variance of the two classes on students' 
mathematical spatial abilities between experimental class I and experimental class II. The testing hypothesis is.

$H_{0}$ : The sample comes from a homogeneous data group variance

Ha: The sample comes from the variance of the data group which is not homogeneous

The $\mathrm{H}_{0}$ test criterion is accepted if the probability ( $\mathrm{sig}$ ) obtained is greater than 0.05 and is rejected in other cases. The output of the homogeneity test of students' mathematical spatial ability data in the experimental class I and experimental class II can be seen in Table 4 below.

Table 4.

Results of the Mathematical Spatial Ability Homogeneity Test

\begin{tabular}{|l|l|l|l|l|l|}
\hline & & $\begin{array}{l}\text { Levene } \\
\text { Statistic }\end{array}$ & df1 & df2 & Sig. \\
\hline Special score & Based on Mean & 1.696 & 1 & 70 & .197 \\
\cline { 2 - 6 } & Based on Median & 1.322 & 1 & 70 & .254 \\
\cline { 2 - 6 } & $\begin{array}{l}\text { Based on Median and } \\
\text { with adjusted df }\end{array}$ & 1.322 & 1 & 69.915 & .254 \\
\cline { 2 - 6 } & Based on trimmed mean & 1.744 & 1 & 70 & .191 \\
\hline
\end{tabular}

Based on Table 4, it can be seen that the probability value (sig) is 0.197 . This shows that the post-test probability (sig) value is greater than 0.05 . This means that the students' mathematical spatial ability data comes from the variance of the same or homogeneous data groups.

\section{Hypothesis testing}

Based on the results of the test requirements that have been met, to test whether there are differences in the spatial abilities and dispositions of students who are taught Realistic Mathematic Education (RME) learning and are taught through STAD type cooperative learning and to test whether there is an interaction between learning and students' initial mathematical abilities spatial and student dispositions.

Hypothesis testing that has been formulated uses two-way analysis of variance using the F statistic with the formula and criteria set. The results of the calculation of the hypothesis test analysis with the help of the SPSS 17 program can be seen in Table 5 below

Table 5.

ANOVA Test of Students' Spatial Mathematical Ability

\begin{tabular}{|l|r|r|r|r|r|}
\hline Source & $\begin{array}{c}\text { Type III Sum } \\
\text { of Squares }\end{array}$ & \multicolumn{1}{c|}{ Df } & Mean Square & \multicolumn{1}{c|}{ F } & \multicolumn{1}{l|}{ Sig. } \\
\hline Corrected Model & $2641.798^{\mathrm{a}}$ & 5 & 528.360 & 5.252 & .000 \\
\hline Intercept & 232300.059 & 1 & 232300.059 & 2309.289 & .000 \\
\hline $\begin{array}{l}\text { students' initial } \\
\text { mathematics abilities }\end{array}$ & 397.200 & 2 & 198.600 & 1.974 & .147 \\
\hline Model & 680.241 & 1 & 680.241 & 6.762 & .011 \\
\hline KAM * Model & 705.814 & 2 & 352.907 & 3.508 & .036 \\
\hline Error & 6639.188 & 66 & 100.594 & & \\
\hline Total & 425305.000 & 72 & & & \\
\hline Corrected Total & 9280.986 & 71 & & & \\
\hline a. R Squared =,285 (Adjusted R Squared =,230) \\
\hline
\end{tabular}


Differences In Spatial Mathematical Ability Of Students Given A Model Learning Realistic Mathematis Education With Stad Type Of Cooperative Learning, Ara Yustiana, Edi Syahputra, Anita Yus

$H_{0} \quad$ : There is no difference in mathematical spatial ability between students who are given Realistic Mathematic Education (RME) learning and cooperative learning type STAD.

$H_{a} \quad:$ There are differences in mathematical spatial abilities between students who are given Realistic Mathematic Education (RME) learning and cooperative learning type STAD.

$H_{0}: \alpha_{i}=0$

$H_{a}: \alpha_{i} \neq 0$

Information:

$\alpha_{\mathrm{i}}$ : The average spatial ability of students due to Realistic learning Mathematic Education (RME)

Based on Table 5, the results of the analysis of variance for the learning model obtained a probability value (sig) for the learning model of 0.011 . Because the probability value (sig) is smaller than 0.05 , which means there is enough evidence to reject $\mathrm{H}_{0}$. So it can be concluded that there are differences in mathematical spatial abilities between students who are given Realistic Mathematic Education (RME) learning and cooperative learning type STAD.

Based on Table 5, the results of the analysis of variance for the students' initial mathematics abilities * model line obtained a probability value (sig) for the students' initial mathematics abilities * model row of 0.036 . Because the probability value (sig) is smaller than 0.05 , which means there is enough evidence to reject $\mathrm{H}_{0}$. So it can be concluded that there is a significant interaction between the learning model and students' initial mathematics abilities on students' mathematical spatial abilities. This can also be described in Figure 1 below.

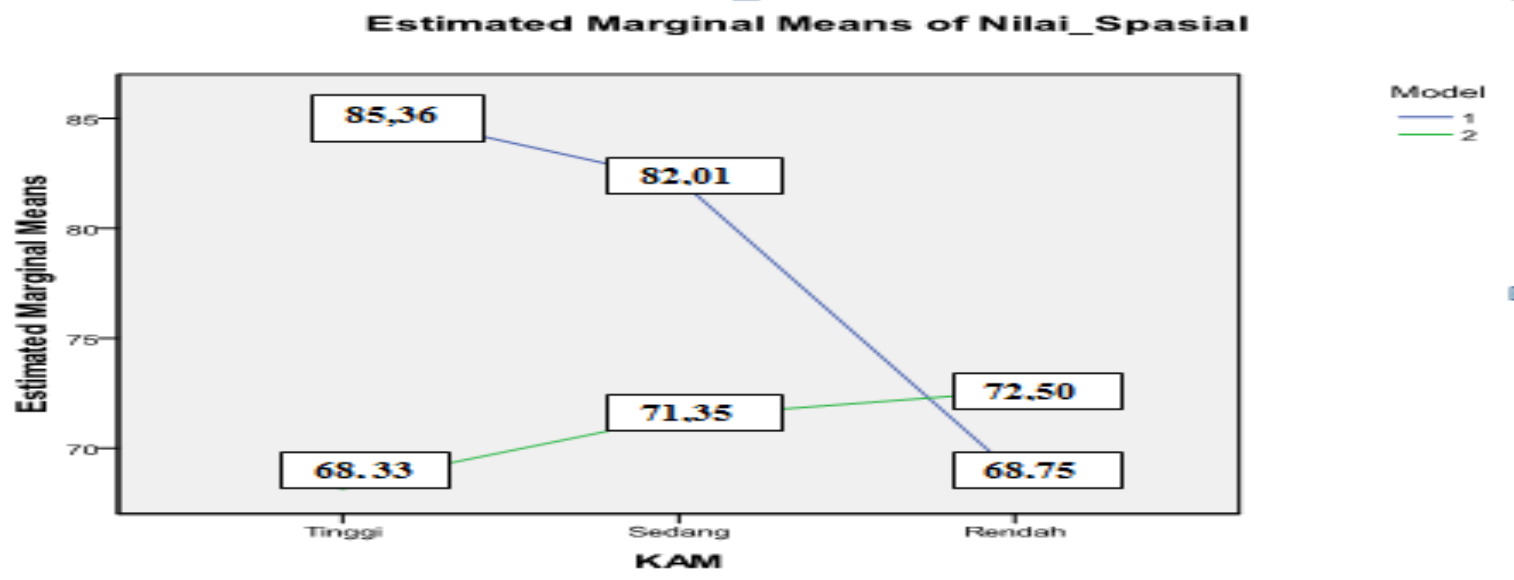

Figure 1.Interaction between Learning Model and students' initial mathematics abilities against Students' Spatial Mathematical Ability

From Figure 1, it can be seen that in the high category KAM with Realistic Mathematic Education (RME) learning has an average of 85.36 while the STAD type cooperative learning has an average of 68.33. The difference in the average mathematical spatial ability between Realistic Mathematic Education (RME) learning and STAD type cooperative learning is 17.03. In the medium category KAM with Realistic Mathematic Education (RME) learning has an average of 82.01 while the cooperative learning type STAD has an average of 71.35 . The difference in the average 
mathematical spatial ability between Realistic Mathematic Education (RME) learning and STAD type cooperative learning is 10.66. In the low category KAM with Realistic Mathematic Education (RME) learning has an average of 68.75 while the STAD type of cooperative learning has an average of 72.50. The difference in the average mathematical spatial ability between Realistic Mathematic Education (RME) learning and STAD type cooperative learning is 3.75. Because the low category KAM in Realistic Mathematic Education (RME) learning is lower than the low category KAM in STAD type cooperative learning so there is an interaction between the learning model and KAM on students' mathematical spatial abilities.

Spatial abilities are mental abilities that are concerned with understanding, manipulating, rotating and interpreting visual relationships. In this study students are said to have spatial abilities if students are able to imagine the shape or position of a geometric object seen from a certain point of view, students are able to state the position between the elements of a shape, students can construct and represent geometric models drawn on the data plane and students can predict and determine the actual size of the visual stimulus of an object.

After doing the research, the results obtained were the results of the research where the average post-test experimental class I was 80.45 and the post-test average experimental class II was 71.32. These results indicate that the students' mathematical spatial abilities in the experimental class I were higher than those in the experimental class II. The statistical test results for the hypothesis are known from the ANOVA results obtained from the probability value (sig) of 0.011 which is smaller than the probability level (sig) of 0.05 . So it can be concluded that in this study there are differences in the mathematical spatial abilities of students taught by Realistic Mathematic Education (RME) and cooperative learning type STAD. In this case, the mathematical spatial abilities of students taught with Realistic Mathematic Education (RME) were higher than those taught by cooperative learning type STAD.

From the observations of the characteristics of Realistic Mathematic Education (RME) learning and STAD type cooperative learning, the occurrence of differences is a natural thing. Theoretically, Realistic Mathematic Education (RME) learning has several advantages. These advantages concern the characteristics of Realistic Mathematic Education (RME) learning, namely using concrete problems (Lubis, Ariswoyo, \& Syahputra, 2020). When facing concrete problems, students will use solving strategies to transform concrete problems into math problems (Sister, Syahputra, \& Sinaga, 2020; Tanjung, Syahputra, \& Irvan, 2020). In this study, students were invited to jointly create mathematical models in the form of mathematical expressions or in the form of diagrams or graphs, either individually or in groups. The model created by students and teachers can increasingly improve students' mathematical spatial, so that efforts to educate students through Mathematic Education (RME) learning can provide good results. As in the results of research conducted by Syahputra (2013) concluded that the spatial abilities of students who were taught using 
a realistic mathematical approach were better than the spatial abilities of students who were taught using a conventional approach. Likewise, the research results of Yulianty (2019) concluded that there were differences in the ability to understand mathematical concepts between students who were taught using a realistic mathematics approach and conventional learning after controlling for students' initial abilities.

In the type of STAD cooperative learning which prioritizes cooperation between students to achieve learning goals. Students in cooperative learning type STAD motivate each other to be better and help those who are in trouble. In cooperative learning type STAD, the teacher gives individual quizzes as feedback to test students' abilities towards the material that has just been studied and presented. This can also encourage students to be more serious when discussing with their group of friends. Seriousness in group learning can help students to solve problems faster when compared to learning individually. STAD type of cooperative learning creates interactions between students and teachers and students. Students play an active role in the STAD-type cooperative learning process and the contribution between students in learning can be seen when discussing with a group of friends to solve the problems contained in LAS and during presentation (presentation of results). Likewise, student-teacher interactions occur during discussions where the teacher must be able to intervene if they find that students are not clear about the instructions or they cannot complete the group assignments given, but must recognize how important the assistance is for students so that they are more dependent on one another. each other, rather than depending on the teacher. In addition, teachers and students in cooperative learning type STAD together make conclusions from the results of the presentations that have been presented. Therefore, the interactions that occur are multi-directional. However, overall the results of students' mathematical spatial abilities learning with Realistic Mathematic Education (RME) were higher than the STAD type of cooperative learning.

\section{CONCLUSION}

Based on the results and discussion of the mathematical spatial abilities of students who learn through Realistic Mathematic Education (RME) learning and cooperative learning, it is concluded that there are significant differences in the mathematical spatial abilities of students who learn through Realistic Mathematic Education (RME) learning and those who learn through cooperative learning. There is an interaction between the learning model and KAM on students' mathematical spatial abilities. This means that the interaction between the learning model (Realistic Mathematic Education (RME) and Cooperative Learning) and KAM has a significant effect on students' mathematical spatial abilities.

\section{REFERENCES}

Aminah, S., Wijaya, T. T., \& Yuspriyati, D. (2018). Analisis Kemampuan Komunikasi Matematis Siswa Kelas Viii Pada Materi Himpunan. Jurnal Cendekia: Jurnal Pendidikan Matematika, 2(1), 15-22. https://doi.org/10.31004/cendekia.v2i1.29 
Bernard, M., Sumarna, A., Rolina, R., \& Akbar, P. (2019). Development of high school student work sheets using VBA for microsoft word trigonometry materials. Journal of Physics: Conference Series, 1315(1). https://doi.org/10.1088/1742-6596/1315/1/012031

Desania, F., Sinaga, B., Lubis, A., \& Syahputra, E. (2020). Analysis of students' critical thinking skills through problem-based learning approach using HOTS questions in SMA N 13 medan. International Journal of Scientific and Technology Research, 9(3), 131-137.

Dewi, D. P., Mediyani, D., Hidayat, W., Rohaeti, E. E., \& Wijaya, T. T. (2019). Analisis Kemampuan Berpikir Kritis Matematis Siswa Smp Pada Materi Lingkaran Dan Bangun Ruang Sisi Datar. JPMI (Jurnal Pembelajaran Matematika Inovatif), $2(6), \quad 371$. https://doi.org/10.22460/jpmi.v2i6.p371-378

Dewi, S. N., Wijaya, T. T., Budianti, A., \& Rohaeti, E. E. (2018). Pengaruh Model Teams Games Tournament Terhadap Kemampuan Pemahaman Matematik Siswa Kelas XI SMK di Kota Cimahi Pada Materi Fungsi Eksponen. WACANA AKADEMIKA: Majalah Ilmiah Kependidikan, 2(1), 99. https://doi.org/10.30738/wa.v2i1.2570

Dini, M., Wijaya, T. T., \& Sugandi, A. I. (2018). Pengaruh Self Confidence Terhadap Kemampuan Pemahaman Matematik Siswa Smp. Jurnal Silogisme, 3(1), 1-7.

Fitri, S., Syahputra, E., \& Syahputra, H. (2019). Blended learning rotation model of cognitive conflict strategy to improve mathematical resilience in high school students. International Journal of Scientific and Technology Research, 8(12), 80-87.

Fitriani, N., Suryadi, D., \& Darhim, D. (2018). the Students' Mathematical Abstraction Ability Through Realistic Mathematics Education With Vba-Microsoft Excel. Infinity Journal, 7(2), 123. https://doi.org/10.22460/infinity.v7i2.p123-132

Hutajulu, M., Wijaya, T. T., \& Hidayat, W. (2019). the Effect of Mathematical Disposition and Learning Motivation on Problem Solving: an Analysis. Infinity Journal, 8(2), 229. https://doi.org/10.22460/infinity.v8i2.p229-238

Kulsum, S. I., Hidayat, W., Wijaya, T. T., \& Kumala, J. (2019). Analysis on high school students' mathematical creative thinking skills on the topic of sets. Jurnal Cendekia : Jurnal Pendidikan Matematika, 03(02), 431-436. https://doi.org/https://doi.org/10.31004/cendekia.v3i2

Lubis, W. A., Ariswoyo, S., \& Syahputra, E. (2020). Kemampuan Pemecahan Masalah Matematika Melalui Pendekatan Pendidikan Matematika Realistik dan Pendekatan Penemuan Terbimbing Berbantuan Autograph. Edumatika: Jurnal Riset Pendidikan Matematika, 3(1), 1. https://doi.org/10.32939/ejrpm.v3i1.483

Napitupulu, W. R., Syahputra, E., \& Sinaga, B. (2020). Development of learning devices based onproblem-based learning assisted adobeflash cs 11 to improve combinatoric ability students. International Journal of Scientific and Technology Research, 9(2), 2219-2227.

Purnama, A., Wijaya, T. T., Dewi, S. N., \& Zulfah, Z. (2020). Analisis Buku Siswa Matematika SMA dari Indonesia dan China Pada Materi Peluang dan Statistik. Jurnal Cendekia: Jurnal .... Retrieved from https://j-cup.org/index.php/cendekia/article/view/305

Sister, D., Syahputra, E., \& Sinaga, B. (2020). Analysis of students' difficulties in mathematical creative thinking on problem-based learning model. International Journal of Scientific and Technology Research, 9(3), 3842-3845.

Syahputra, E., \& Utami, D. R. (2019). The design of IQF-oriented ARCS-based learning model. Journal of Physics: Conference Series, 1315(1). https://doi.org/10.1088/1742$6596 / 1315 / 1 / 012065$ 
Tamur, M., Juandi, D., \& Adem, A. M. G. (2020). Realistic Mathematics Education in Indonesia and Recommendations for Future Implementation: A Meta-Analysis Study. JTAM | Jurnal Teori Dan Aplikasi Matematika, 4(1), 17. https://doi.org/10.31764/jtam.v4i1.1786

Tanjung, D. F., Syahputra, E., \& Irvan, I. (2020). Problem Based Learning, Discovery Learning, and Open Ended Models: An experiment On Mathematical Problem Solving Ability. JTAM| Jurnal Teori Dan Aplikasi Matematika, 4(1), 9. https://doi.org/10.31764/jtam.v4i1.1736

Wijaya, T. T., Dewi, N. S. S., Fauziah, I. R., \& Afrilianto, M. (2018). Analisis Kemampuan Pemahaman Matematis Siswa Kelas IX Pada Materi Bangun Ruang. UNION: Jurnal Ilmiah Pendidikan Matematika, 6(1), 19-28. https://doi.org/10.30738/.v6i1.2076

Wijaya, T. T., Purnama, A., \& Tanuwijaya, H. (2020). Pengembangan Media Pembelajaran Berdasarkan Konsep Tpack pada Materi Garis dan Sudut Menggunakan Hawgent Dynamic Mathematics Software. JPMI - Jurnal Pembelajaran Matematika Inovatif, 3(3), 205-214. https://doi.org/10.22460/jpmi.v1i3.205-214

Wijaya, T. T., Sukma, M., Purnama, A., \& Tanuwijaya, H. (2020). Pengembangan media pembelajaran berbasis tpack menggunakan hawgent dynamic mathematics software. Journal of Elementary Education, 03(03), 64-72.

Wijaya, T. T., Tang, J., \& Purnama, A. (2020). Developing an interactive mathematical learning media based on the tpack framework using the hawgent dynamic mathematics software. In Lecture Notes of the Institute for Computer Sciences, Social-Informatics and Telecommunications Engineering, LNICST. https://doi.org/10.1007/978-3-030-60036-5_24

Wijaya, T. T., Ying, Z., \& Suan, L. (2020). Using Geogebra in Teaching Plane Vector. Journal of Innovative Mathematics Learning, 3(1), 15-23.

Zhang, X., Zhou, Y., \& Wijaya, T. T. (2020). Hawgent Dynamic Mathematics Software to Teach Line and Angle. JNPM (Jurnal Nasional Pendidikan Matematika), 4(2), 237-247. 